Canadian Journal of Fisheries and Aquatic Sciences, 62(11), pp. 2649-2660 (2005). |

http://pubs.nrc-cnrc.gc.ca/eng/home.html

http://article.pubs.nrc-

cnrc.gc.ca/RPAS/rpv?hm=HInit\&calyLang=eng\&journal=cjfas\&volume=62\&afpf=f05-171.pdf ISSN $1205-75334$

doi:10.1139/f05-171 |

(c) 2005 NRC Canada 


\title{
Effects of storms, angling, and nest predation during angling on smallmouth bass (Micropterus dolomieu) nest success
}

\author{
Geoffrey B. Steinhart, Nancy J. Leonard, Roy A. Stein, and \\ Elizabeth A. Marschall
}

\begin{abstract}
We studied how storms, angling, and nest predation during angling affected smallmouth bass (Micropterus dolomieu) nest survival in the Bass Islands, Lake Erie, Ohio, USA. Increasing angler effort and introduction of an exotic nest predator, round goby (Neogobious melanostomus), have raised concerns about smallmouth bass recruitment in Lake Erie. We surveyed smallmouth bass nests and calculated daily survival rates for nests assigned to different angling treatments: control, angling without predation, or angling with predation treatments. Only $30 \%$ of control nests were successful compared with $11 \%$ of angling without predation and $14 \%$ of angling with predation treatments. We used the Mayfield method and maximum likelihood models in the program MARK to estimate the survival rates for nests of different treatments and exposed to different numbers of storms. Although nest predators consumed about $35 \%$ of broods during angling, daily nest survival rates of both angling treatments were similar. Angling reduced nest survival compared with controls by approximately $5 \%$. Storms reduced both nest success and daily survival. The best model predicting daily nest survival included the added effects of angling treatment and number of storms. Thus, whereas storms and angling affected smallmouth bass nest survival, nest predation during angling did not.
\end{abstract}

Résumé : Nous avons étudié de quelle manière les tempêtes, la pêche sportive et la prédation au nid durant la pêche affectent la survie au nid de l'achigan à petite bouche (Micropterus dolomieu) dans les îles Bass, lac Érié, Ohio, E.-U. L'augmentation de l'effort de pêche sportive et l'introduction d'un prédateur des nids exotique, le gobie à taches noires (Neogobius melanostomus), génèrent des inquiétudes sur le recrutement de l'achigan à petite bouche au lac Érié. Nous avons inventorié des nids d'achigans à petite bouche et calculé les taux journaliers de survie dans des nids soumis à diverses conditions de pêche, soit des conditions témoins, de la pêche sportive sans prédation et de la pêche sportive avec prédation. Seulement $30 \%$ des nids témoins ont eu du succès; par comparaison, $11 \%$ des nids soumis à la pêche sportive mais non à la prédation et $14 \%$ des nids soumis à la pêche et la prédation ont eu du succès. Nous avons utilisé la méthode de Mayfield et les modèles de vraisemblance maximale du logiciel MARK pour estimer les taux de survie dans les nids soumis aux diverses conditions expérimentales et exposés à des nombres variables de tempêtes. Bien que les prédateurs des nids consomment environ $35 \%$ des portées durant la période de pêche, les taux journaliers de survie au nid dans les deux conditions de pêche sont semblables. La pêche sportive réduit la survie au nid d'environ $5 \%$ par rapport aux témoins. Les tempêtes réduisent tant le succès de la nidification que la survie journalière. Le meilleur modèle pour prédire la survie journalière au nid comprend les effets cumulés des conditions de pêche sportive et du nombre de tempêtes. Ainsi, alors que les tempêtes et la pêche sportive affectent la survie des achigans à petite bouche au nid, la prédation des nids durant la période de pêche n'a pas cet effet.

[Traduit par la Rédaction]

\section{Introduction}

Nest success is a critical component in the reproductive biology of species providing parental care for offspring that remain in a confined nest (e.g., many fish, birds, reptiles, and amphibians). Environmental conditions (Townshend and Wootton 1985; Goff 1986), parents' ability to care for their young (Ridgway and Shuter 1994), and parental behavior (Sargent 1988; Ghalambor and Martin 2000) all influence nesting success. In turn, reproductive success can influence population dynamics and affect the evolution of parental behavior (Gross and MacMillan 1981; Popiel et al. 1996). As anthropogenic impacts on climate and species invasions become more widespread, understanding their impacts on nest

Received 28 December 2004. Accepted 24 May 2005. Published on the NRC Research Press Web site at http://cjfas.nrc.ca on 19 October 2005.

J18480

G.B. Steinhart, ${ }^{1,2}$ N.J. Leonard, ${ }^{3}$ R.A. Stein, and E.A. Marschall. Aquatic Ecology Laboratory, Department of Evolution, Ecology, and Organismal Biology, Ohio State University, 1314 Kinnear Road, Columbus, OH 43212-1156, USA.

${ }^{1}$ Corresponding author (e-mail: steinhart.3@osu.edu).

${ }^{2}$ Present address: Department of Natural Resources, 208 Fernow Hall, Cornell University, Ithaca, NY 14853-3001, USA.

${ }^{3}$ Present address: Great Lakes Fishery Commission, 2100 Commonwealth Boulevard, Suite 100, Ann Arbor, MI 48105, USA. 
success is of growing importance. For example, climate warming (Shuter and Post 1990), exotic nest predators (Janssen and Jude 2001), and the combination of habitat destruction and brood parasites (Pease and Grzybowski 1995) affect reproductive success. Therefore, understanding the mechanisms controlling nest success will allow better predictions of how environmental changes may affect future reproductive success (Shuter and Post 1990; Ricciardi and Rasmussen 1998).

We chose to examine nest success of smallmouth bass (Micropterus dolomieu), where males alone care for their offspring for up to 6 weeks (Friesen 1998; Knotek and Orth 1998). Care involves nearly constant fanning of eggs and protection of offspring from nest predators (Hinch and Collins 1991). During this time, smallmouth bass do not actively forage for prey, although they may consume a limited number of prey available near the nest (Mackereth et al. 1999). Thus, parental care is energetically costly for smallmouth bass (Gillooly and Baylis 1999; Mackereth et al. 1999; Steinhart et al. 2005). Smallmouth bass nest success is influenced by storms (Goff 1986), temperature fluctuations (Friesen 1998; Knotek and Orth 1998), angling (Philipp et al. 1997; Suski et al. 2003), and nest predation (Hinch and Collins 1991; Knotek and Orth 1998).

We examined smallmouth bass nest success in Lake Erie, Ohio, USA, where storms, angling, and nest predators may well determine smallmouth bass nest survival. Lake Erie is a large lake with a long fetch; thus, storms can produce large waves capable of destroying smallmouth bass nests (Goff 1986). Nest predators, which can destroy unguarded smallmouth bass nests within $24 \mathrm{~h}$ (Hinch and Collins 1991; Kieffer et al. 1995), are extremely abundant in Lake Erie since the introduction and spread of the round goby (Neogobious melanostomus) (Charlebois et al. 1997). Round gobies are known egg predators with an average density of 7 individuals $\mathrm{m}^{-2}$ (Johnson et al. 2005) and sometimes exceeding 100 individuals $\cdot \mathrm{m}^{-2}$ (Chotkowski and Marsden 1999). In addition, angling is allowed during the nesting season in Ohio waters of Lake Erie, so anglers can remove guarding males from their nests. When the guarding male smallmouth bass is removed, the nest becomes more susceptible to predators (Kieffer et al. 1995; Philipp et al. 1997). Even if anglers practice catch-and-release techniques, nest predators consume offspring while the guarding male is absent (Steinhart et al. 2004). In addition, the stress of angling may result in nest abandonment (Philipp et al. 1997).

Herein, we describe how storms, angling, and nest predation during angling affected smallmouth bass nest success in Lake Erie. Specifically, we sought to determine which factors were more important in determining smallmouth bass nest success and if factors interacted to affect nest success. To do this, we first defined wind speeds that could cause smallmouth bass nest failures. Next, we designed an experiment to separate the effects of storms, angling, and nest predation during angling on smallmouth bass nest success. Assessing nest survival has traditionally relied on reporting only percent nest success or by using techniques that require scientists to make assumptions about nest failure date or causes of nest failures (Mayfield 1961). We compared results from the Mayfield method with a more recent tech- nique (the program MARK) that allows for individual and time-dependent covariates of nesting data (Burnham and Anderson 1998; White and Burnham 1999; Dinsmore et al. 2002).

\section{Methods}

\section{Nest success surveys}

We conducted nest surveys at three locations in the Bass Islands, Lake Erie, to monitor smallmouth bass nest survival during the 1999-2001 spawning seasons (Fig. 1). Spawning smallmouth bass were first observed in early May in each year and we surveyed nests during 24 May - 3 July 1999, 9 May - 11 July 2000, and 9 May - 9 July 2001. During 1999, we were still developing our methods and the only data comparable among years were from after 24 May. Sites were revisited as frequently as possible (mean every 3 days, range 1-10 days). Sites were known spawning areas with similar substrate (predominantly cobble over a cohesive-clay base) and depth (2.5-3 m deep) but were exposed to different ranges of winds (i.e., different exposure to storms; Fig. 1). Within each site, we repeatedly sampled one or two linear transects $(6 \mathrm{~m} \times 100 \mathrm{~m}, 1999)$ or one $50 \mathrm{~m}$ diameter circle (2000-2001). Latitude and longitude of each site were recorded in 1999 and were used to position sites in subsequent years. Nests were individually marked with numbered tiles. In both 2000 and 2001, we found tiles from nests marked in 1999; thus, our sites were located within $100 \mathrm{~m}$ of each other across years.

For each survey, a pair of SCUBA divers swam along a metered line marking the transect (1999) or swam in concentric circles by holding a metered line attached to a buoy at the site's center (2000 and 2001) until they had surveyed the entire site. When a new nest was discovered, we marked it with a numbered tile and recorded its location on a site map, which allowed us to relocate nearly every nest during each survey. For all nests, we recorded offspring developmental stage as unhatched embryos (i.e., fertilized eggs), hatched embryos, larvae, or juveniles. Free-swimming larvae and juveniles are often widely dispersed from nest during the day, making it difficult to locate the nest, and they may leave the brood at any time. Therefore, we defined a successful nest as any nest that we observed with free-swimming larvae (a common definition of a successful smallmouth bass nest). Defining successful nests as nests producing larvae may overestimate true nest success because offspring survival increases if offspring remain until metamorphosing into juveniles. When we were unsure of a nest's fate (e.g., the nest was deemed close to reaching the larval stage and we were unable to sample it for several days to be sure if it was successful) or a nest failed before we were able to assign it to a treatment, it was excluded from all analyses except the Mayfield estimates of daily survival (see below).

\section{Angling experiment}

We assigned each nest, consecutively, to one of three treatments: ( $i$ ) control (unmanipulated), (ii) angling without predation (the nest was guarded by a diver during the male's absence), or (iii) angling with predation (predators were allowed to enter the unguarded nest). The two angling treat- 
Fig. 1. Map showing study sites for nesting smallmouth bass (Micropterus dolomieu) in the Bass Islands, Lake Erie, Ohio, USA. Arcs indicate the approximate wind ranges included when calculating number of storms at each site: Perry's Monument $\left(\mathrm{PM}, 60^{\circ}-180^{\circ}\right)$, Sonny's Marina (SO, $210^{\circ}-280^{\circ}$ ), and Gray's Bay (GB, $290^{\circ}-315^{\circ}$ and $\left.10^{\circ}-60^{\circ}\right)$. Continuous wind data were obtained from NOAA Station SBIO1 located on South Bass Island.

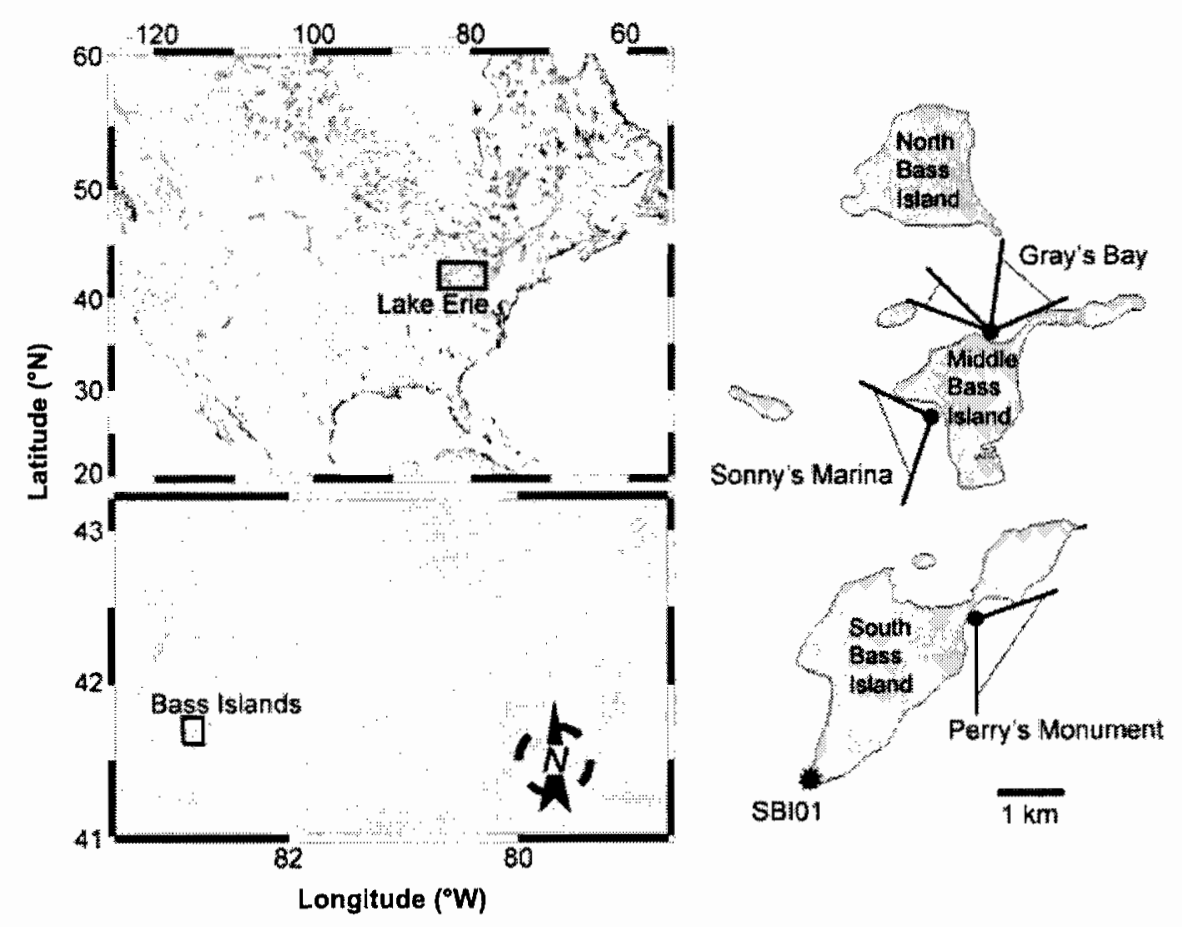

ments were designed to test direct effects of angling on nest survival (angling without predation) and the combined effects of angling and nest predation occurring while guarding males were temporarily removed (angling with predation). To simulate catch-and-release angling, SCUBA divers caught nest-guarding males using a rod and reel with a soft-plastic artificial bait on a weighted single hook as a lure. We angled nest-guarding males an average of 2 days after their nest was discovered (range 0-16 days). Divers remained suspended above and to the side of the nest, careful not to disturb the substrate, and extended the rod to place the lure on the substrate within the nest. Once the smallmouth bass was hooked, the diver swam to the support boat and passed the rod to a person in the boat, who quickly reeled in the guarding male. Angled fish were weighed, measured, and jawtagged (Monel metal jaw tag, size 10) before release (mean angling plus processing time $125 \mathrm{~s}$, range $37-238 \mathrm{~s}$ ). For the angling without predation treatment, a diver remained by the nest and chased potential predators using hand motions to prevent predators from entering the nest while the guarding smallmouth bass was absent. Nests were guarded until males returned (average return time after release 208 s, range 12$885 \mathrm{~s}$ ). Al] males were returned to their nests within $15 \mathrm{~min}$ after their release, except one male who did not return until divers left, but this male was seen guarding its nest the next day. During experimental angling, angling with predation treatment nests lost 400-1000 offspring (approximately $25 \%$ of the brood; Steinhart et al. 2004). Round gobies were the dominant predator, $99 \%$ of all predators observed (Steinhart et al, 2004). Control nests, however, were unlikely to experi- ence any brood predation because in $10 \mathrm{~h}$ of video observations, we only once saw a round goby or any other predator consume smallmouth bass offspring while a nest was guarded (Steinhart et al. 2004). No predation during angling was observed in the angling without predation treatment. We compared nest success among treatments using a $\chi^{2}$ test $(\alpha=$ 0.05 for all tests).

\section{Defining a storm}

To determine the strength and duration of winds required to destroy smallmouth bass nests, we monitored egg losses from artificial nests placed in each survey site during 24 May - 11 July 2000 . Artificial nests $(21.6 \mathrm{~cm}$ in diameter and $3 \mathrm{~cm}$ tall) were constructed by embedding limestone rocks of two different size classes (small $=3.8 \mathrm{~cm} \pm 0.7$, large $=6.2 \mathrm{~cm} \pm 1.2)$ in concrete $\left(\right.$ Kwikcrete $\left.{ }^{\mathrm{TM}}\right)$. After determining the mean size $(2.6 \mathrm{~mm}$ in diameter $)$ and specific gravity (0.033) of unfertilized smallmouth bass eggs (Crisp 1989; Dudley and Platania 1999), we found a polystyrene bead that mimicked the size and specific gravity of real eggs. Because smallmouth bass eggs adhere to the substrate after fertilization, we experimented with various adhesives to find one that mimicked the adhesive strength of real eggs. Adhesiveness of artificial eggs held to rocks by compounds was compared with that of egg-covered rocks collected from smallmouth bass nests in Lake Erie. Adhesive strength was tested in a large aquarium, with adjustable flow, by incrementally moving egg-covered rocks closer and closer to the flow source. We recorded distance from the nozzle where $50 \%$ of eggs had been washed from the rock. This 
Table 1. Model descriptions and notations for models of daily survival of smallmouth bass (Micropterus dolomieu) nests tested using the program MARK.

\begin{tabular}{|c|c|c|}
\hline Model description & Model & Notation \\
\hline 1. Single estimate of survival & $Y_{i}=\beta_{0}+\varepsilon_{i}$ & $S_{(0)}$ \\
\hline 2. Site only & $Y_{i}=\beta_{0}+\beta_{1}$ site $_{1}+\beta_{2}$ site $_{2}+\varepsilon_{i}$ & $S_{(\text {site })}$ \\
\hline 3. Nest treatment only & $Y_{i}=\beta_{0}+\beta_{1}$ trt $_{1}+\beta_{2}$ trt $_{2}+\varepsilon_{i}$ & $S_{(\mathrm{trt})}$ \\
\hline 4. Storms only & $Y_{i}=\beta_{0}+\beta_{1}$ storms $+\varepsilon_{i}$ & $S_{\text {(storms) }}$ \\
\hline 5. Treatment plus storms & $Y_{i}=\beta_{0}+\beta_{1}$ trt $_{1}+\beta_{2}$ trt $_{2}+\beta_{3}$ storms $+\varepsilon_{i}$ & $S_{\text {(trt+storms) }}$ \\
\hline 6. Treatment and storms & $Y_{i}=\beta_{0}+\beta_{1}$ trt $_{1}+\beta_{2}$ trt $_{2}+\beta_{3}$ storms $+\beta_{4}$ storms $\cdot \operatorname{trt}_{1}+\beta_{5}$ storms $\cdot \operatorname{trt}_{2}+\varepsilon_{i}$ & $S_{\text {(trtxstorms) }}$ \\
\hline 7. Treatment plus storm hours & $Y_{i}=\beta_{0}+\beta_{1}$ trt $_{1}+\beta_{2}$ trt $_{2}+\beta_{3}$ storm hours $+\varepsilon_{i}$ & $S_{\text {(trt }+ \text { storm hours) }}$ \\
\hline
\end{tabular}

Note: Model description includes the model number referenced in the text and the variables included in the model.

Fig. 2. Smallmouth bass (Micropterus dolomieu) percent nest success in the Bass Islands, Lake Erie, during 1999-2001 for (a) Perry's Monument, (b) Gray's Bay, (c) Sonny's Marina, and (d) all sites combined. Successful nests were those nests producing free-swimming larvae. Nests were assigned to a control treatment (only observation), angling without predation treatment (guarding male smallmouth bass temporarily removed by angling and nest guarded during his absence), or angling with predation treatment (guarding male smallmouth bass temporarily removed by angling and predators allowed to enter the unguarded nest).

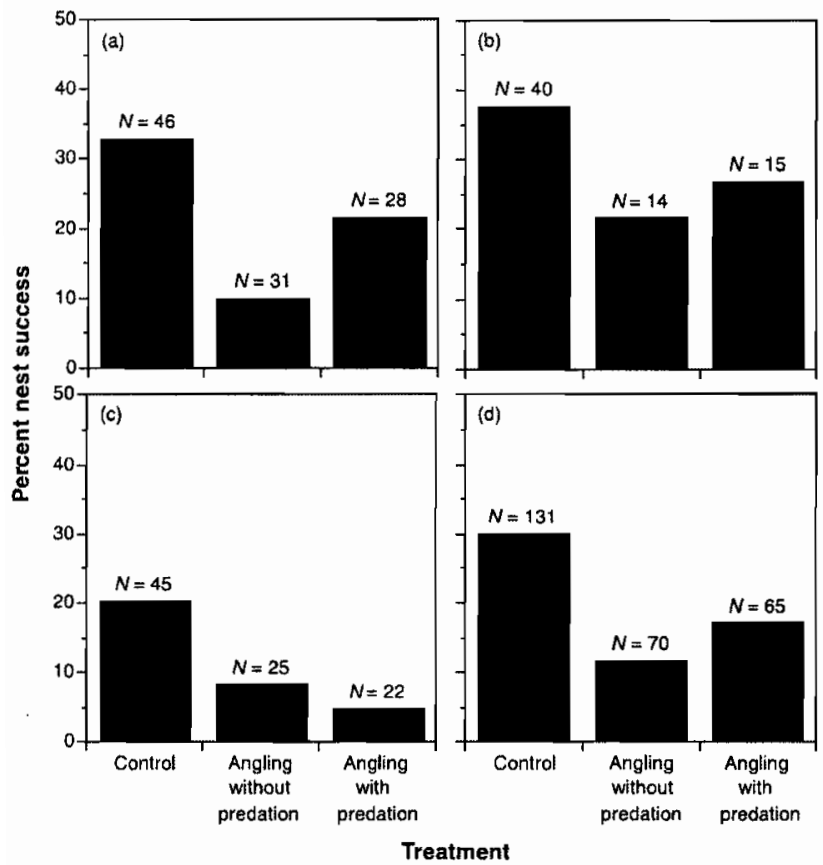

process was repeated for multiple flows and adhesives and for rocks covered with real smallmouth bass eggs. Ultimately, a petroleum-based cream (Vaseline ${ }^{\mathrm{TM}}$ ) most closely mimicked the adhesiveness of real smallmouth bass eggs.

Artificial nests, each with 50 artificial eggs, were placed in situ at the three sites to estimate egg loss to waves and currents. At each site, four nests, two each of the different substrates, were deployed at the center of the study sites at the 3-m depth on 35 different site-days (total 140 artificial nests). All nests were left in situ overnight (mean $26 \mathrm{~h}$, range $17-48 \mathrm{~h}$ ). After retrieving nests, we counted the re- maining eggs and averaged number of eggs for nests of similar substrate and compared mean egg number across substrate size with a paired $t$ test to determine if substrate size affected egg loss.

To determine storm exposure for each artificial nest deployment, we used continuous wind data $(1-\mathrm{h}$ mean speed and direction) from a National Oceanic and Atmospheric Administration (NOAA) weather station located on South Bass Island (Station SBIO1; Fig. 1). We included only winds directed into each of our study sites (Fig. 1). Using egg loss and wind data from only one of the sites, we used a twodimensional Kolmogorov-Smirnov test (2DKS test) (Garvey et al. 1998) to look for a relationship between wind speed (metres per second) and number of eggs lost from the artificial nests. The 2DKS test is useful for detecting nonrandom patterns in data and tests the hypothesis that the $x$ and $y$ data are distributed independently. The lowest $P$ value was found using a wind speed of $7 \mathrm{~m} \cdot \mathrm{s}^{-1}$, which is the same wind speed where wave heights begin to increase (data from NOAA Station SBIO1). Next, we used the 2DKS to test for a threshold number of hours of continuous wind with speeds $\geq 7 \mathrm{~m} \cdot \mathrm{s}^{-1}$ that resulted in significant egg losses from artificial nests at all sites. The threshold, provided by the 2DKS test, is the $x, y$ pair where the maximum difference between the actual data and independently distributed data occurred. We used this threshold (hours of continuous wind speeds $\geq 7 \mathrm{~m} \cdot \mathrm{s}^{-1}$ ) as our definition of a storm that was capable of destroying real smallmouth bass nests in our sites. Because changes in water temperature may lead to nest failure (Friesen 1998; Knotek and Orth 1998), we placed Hobo ${ }^{\circledR}$ temperature loggers at the 3-m depth in the center of each site during 2000 and 2001.

\section{Mayfield estimation of nest survival}

We estimated daily nest survival (the probability of a nest surviving a single day) for smallmouth bass nests using the Mayfield method (Mayfield 1961, 1975). The Mayfield methods estimates daily survival rate $(s)$ as

$$
s=1-\frac{\text { number of failed nests }}{\text { total days of exposure for all nests }}
$$

Total days of exposure is the sum of all days spanned from when nests were first seen to when they succeeded or failed. For example, 10 exposure-days could represent the exposure of one nest for 10 days, five nests for 2 days each, or 10 nests for 1 day each. When a nest failed, the failure date was assumed to have occurred midway between the last time it 
Table 2. Smallmouth bass (Micropterus dolomieu) nest success (shown in descending order of percentage of nests reaching the free-swimming larval stage) for various lakes and rivers including sample year(s), number of nests observed $(N)$, percent nest success, and data source.

\begin{tabular}{llrll}
\hline Study site & Year(s) & $N$ & Success (\%) & Study \\
\hline Nebish Lake, Wisconsin & 1985 & 49 & 96 & Raffetto et al. 1990 \\
Nebish Lake, Wisconsin & 1983 & 45 & 93 & Raffetto et al. 1990 \\
South Branch Lake, Maine & 1972 & 26 & 88 & Neves 1975 \\
Lake Erie, Ontario & 1983 & 87 & 87 & Goff 1986 \\
Nebish Lake, Wisconsin & 1984 & 47 & 87 & Raffetto et al. 1990 \\
Lake Huron, Ontario & 1973 & 13 & 85 & Hurley 1975 \\
Mississippi River, Ontario & $1990-1995$ & 452 & 84 & Philipp et al. 1997 \\
Lake Opeongo, Ontario & 1993 & 76 & 82 & Friesen 1998 \\
Lake Opeongo, Ontario & 1989 & 123 & 79 & Friesen 1998 \\
Lake Opeongo, Ontario & 1992 & 92 & 77 & Friesen 1998 \\
Lake Opeongo, Ontario & 1988 & 63 & 75 & Friesen 1998 \\
South Branch Lake, Maine & 1971 & 15 & 67 & Neves 1975 \\
North Anna River, Virginia & 1994 & 56 & 64 & Knotek and Orth 1998 \\
St. Lawrence River, Ontario & $1990-1995$ & 1864 & 58 & Philipp et al. 1997 \\
Lake Michigan, Michigan & 1954 & 20 & 55 & Latta 1956 \\
Lake Michigan, Michigan & 1955 & 28 & 54 & Latta 1956 \\
Charleston Lake, Ontario & $1990-1995$ & 1536 & 54 & Philipp et al. 1997 \\
Lake Opeongo, Ontario & 2001 & 36 & 50 & Steinhart 2004 \\
Lake Opeongo, Ontario & 1991 & 72 & 47 & Friesen 1998 \\
Tadenac Lake, Ontario & 1966 & 20 & 45 & Turner and MacCrimmon 1970 \\
Lake Opinicon, Ontario & $1990-1995$ & 1376 & $44-63$ & Philipp et al. 1997 \\
North Anna River, Virginia & 1992 & 105 & 43 & Lukas and Orth 1995 \\
Lake Erie, Ohio & 1999 & 54 & 41 & This study \\
Lake Erie, Ontario & 1982 & 33 & 33 & Goff 1986 \\
Lake Huron, Ontario & 1974 & 40 & 33 & Hurley 1975 \\
Lake Erie, Ohio & 2001 & 40 & 23 & This study \\
Lake Erie, Ohio & 2000 & 21 & This study \\
\hline
\end{tabular}

was found occupied and when it was found abandoned (Mayfield 1961, 1975). The Mayfield method allows data from nests of unknown fate to be included by using the data prior to when the fate could not be determined (Mayfield 1961, 1975); thus, we included data from all nests in the Mayfield calculations. Despite its assumptions, the Mayfield method has proven fairly robust for estimating nest survival (Johnson 1979; Farnsworth et al. 2000; Manly and Schmutz 2001). We first calculated $s$ for each treatment and tested for a significant difference using a $z$ test (Johnson 1979). But we were also interested in how nest survival was affected by the number of storms that a nest experienced. Mayfield $(1961,1975)$ calculated separate estimates of $s$ for different brood stages (i.e., eggs and fledglings) by splitting the number of failed nests and days of exposure for the stages. In a similar fashion, we calculated separate survival estimates based the number of storms that a nest experienced (zero, one, or two storms) within each angling treatment.

\section{MARK estimation of nest survival}

In addition to the Mayfield method, we used the nest survival model in the program MARK to explore the effects of anglers, predators, and storms on daily nest survival (White and Burnham 1999). While the Mayfield method makes certain assumptions about failure date, MARK uses maximum likelihood models to estimate daily nest survival, thereby avoiding assumptions about nest failure. MARK has a nest success model that is completely described in Dinsmore et al. (2002). MARK is preferable to other techniques because it allows the user to include individual, group, and timespecific covariates when estimating nest survival (Dinsmore et al. 2002). We limited our analyses to a set of predetermined models that explored the effects of nest treatment (control, angling without predation, and angling with predation), sample site, and storms on smallmouth bass daily nest survival. For angled nests, nest histories included only days postangling.

Our candidate models did not include the direct effects of day or year to estimate nest survival. Because storms occurred frequently, our surveys were sometimes separated by several storms, and not all nests were seen on every day; estimating daily survival for 63 intervals, three sites, three treatments, and three years would result in estimation of more parameters than we deemed possible for our sample size. We ignored the effect of year, independent of site, in our model because year effects would be confounded, as we had only control treatments during 1999 but applied control, angling with nest predation, and angling without nest predation treatments during 2000-2001. Including storms as a covariate indirectly accounted for annual effects, as models including storms were nested within models containing both site and year. The storm covariate was the number of storms, 
as defined by our artificial nest experiment, occurring during survey periods for each combination of site and year (i.e., nine unique storm values). Because we empirically defined a storm from artificial nest experiments at each site and because our sample sites were all of similar depths, we felt that storms would have similar effects regardless of site or year. Models that incorporated one or more covariates used the logit link function and all other models used the sine link function (Burnham and Anderson 1998; Dinsmore et al. 2002).

We began with the null model, estimating a single mean daily nest survival without inclusion of any factors (model 1; Table 1). We then looked at each of three factors individually: spawning site (Perry's Monument, Gray's Bay, and Sonny's Marina (model 2)), nest treatment (control, angling without predation, and angling with predation (model 3)), and storms (number of storms in a given year at each site (model 4)). After determining the effect of storms alone, we explored whether nest treatment affected nest survival when survival estimates were constrained by the effect of storms: an additive effect (both storms and nest treatment affected daily nest survival (model 5)) and the interaction of the two (storms affected daily survival of nest treatments differently (model 6)). In case our definition of a storm was not an accurate description of an event that could destroy smallmouth bass nests, we also tested a model that constrained daily nest survival by the total hours of wind speeds $\geq 7 \mathrm{~m} \cdot \mathrm{s}^{-1}$ at each site-by-year combination (Model 7).

We compared the fit of models using Akaike's Information Criterion (AIC) (Akaike 1985). Models were ranked according to $\mathrm{AIC}_{\mathrm{c}}$ (Burnham and Anderson 1998; Dinsmore et al. 2002). Differences in $\mathrm{AIC}_{c}\left(\triangle \mathrm{AIC}_{\mathrm{c}}\right)$ were used to determine which model(s) provided the best fit for nest survival (Burnham and Anderson 1998; Dinsmore et al. 2002). As a rule of thumb, a $\triangle \mathrm{AIC}_{\mathrm{c}}$ value $<2$ indicates equal support for the candidate models, and $\triangle \mathrm{AIC}_{\mathrm{c}}$ values $>7$ indicate considerable support for a difference between models (Burnham and Anderson 1998). In addition, normalized Akaike weights $\left(w_{i}\right)$ were used to evaluate the degree of uncertainty for model selection (Burnham and Anderson 1998). Akaike weights were used to measure the model likelihood of the better fitting model in relation to a poorer fitting model: the ratio of two $w_{i}$ values, the relative plausibility, is interpreted as the likelihood of the better model (Burnham and Anderson 1998).

\section{Results}

\section{Nest success}

We monitored nest success of 318 smallmouth bass nests during the three years (131 controls, 70 angling without predation, 65 angling with predation nests, and 52 nests that were not assigned to a treatment or had unknown fates). Average nest density across all sites and years was 0.0064 nest $\cdot \mathrm{m}^{-2}$ (range $0.0014-0.0210$ ). There was no difference in total length of males assigned to the angling without predation (mean total length $=375 \mathrm{~mm}$ ) and the angling with predation treatments (mean total length $=367 \mathrm{~mm})(t=$ 1.15 , df $=133, P=0.25$ ). Male length was not measured for control treatments, but given our systematic assignment of treatments, we assumed that there was no difference in
Fig. 3. Smallmouth bass (Micropterus dolomieu) nest success (control nests only) as a function of number of storms occurring at different sampling sites ( $\boldsymbol{\square}$, Perry's Monument; $\boldsymbol{0}$, Gray's Bay; A, Sonny's Marina) during the 1999-2001 spawning seasons in the Bass Islands, Lake Erie (percent success $=60-5.9 \times$ number of storms; $r^{2}=0.55, P=0.02$ ). The number of storms was determined only from the dates when there were active control treatment nests containing hatched or unhatched embryos. Successful nests were defined as any nest producing free-swimming larvae. Nest success data were arcsine square root transformed to calculate the regression equation, but the figure is based on raw data.

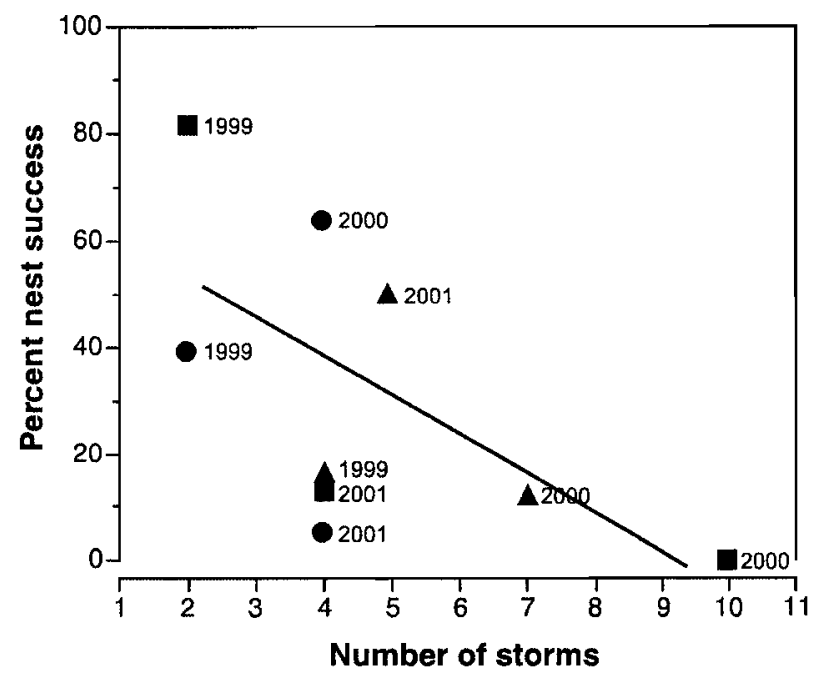

length of these males compared with the angling treatments. Male length is often related to the number of eggs that they receive (Knotek and Orth 1998; Mackereth et al. 1999). Regardless of the relationship between male length and brood number, we assumed that there was no difference in brood number among treatments because males were of similar lengths. In addition, there was no difference in the number of days between when nests were first seen and the date when the male was angled for the angling without predation (2.1 days) and angling with predation treatments (2.3 days) $(t=-0.27, \mathrm{df}=133, P=0.78)$. Angling occurred most frequently during the unhatched embryo stage (77\% of angling without predation nests and $78 \%$ of angling with predation nests) with the remainder during the hatched embryo stage.

Nest success varied by site and treatment (Fig. 2), with treatment having a significant effect on nest success $\left(\chi^{2}=\right.$ 11.18 , df $=2, P=0.004$ ). Nest success did not differ between the angling without predation and angling with predation treatments $\left(\chi^{2}=0.18\right.$, df $\left.=1, P=0.68\right)$ despite significant losses of offspring from angling with predation nests (Steinhart et al. 2004). Inspection of the data, including $\chi^{2}$ residuals, found that control nests had higher nest success (29.8\%) than nests exposed to either the angling without predation treatment $(11.4 \%)$ or the angling with predation treatment $(14.0 \%)$. Smallmouth bass nest success in Lake Erie was lower than reported for many other systems (Table 2). For the control treatment nests, $47 \%$ of the failures contained unhatched embryos and the remainder contained hatched embryos. 
Fig. 4. Water temperatures (solid lines) and wind speeds (broken shaded lines) during the 2000-2001 spawning seasons in the Bass Islands, Lake Erie, for (a) Perry's Monument, $(b)$ Gray's Bay, and (c) Sonny's Marina. Only winds blowing into a particular site are shown. The horizontal dotted line marks both the temperature at which smallmouth bass (Micropterus dolomieu) typically begin to spawn $\left(15^{\circ} \mathrm{C}\right)$ and the minimum wind speeds for our definition of a storm $\left(7 \mathrm{~m} \cdot \mathrm{s}^{-1}\right)$.
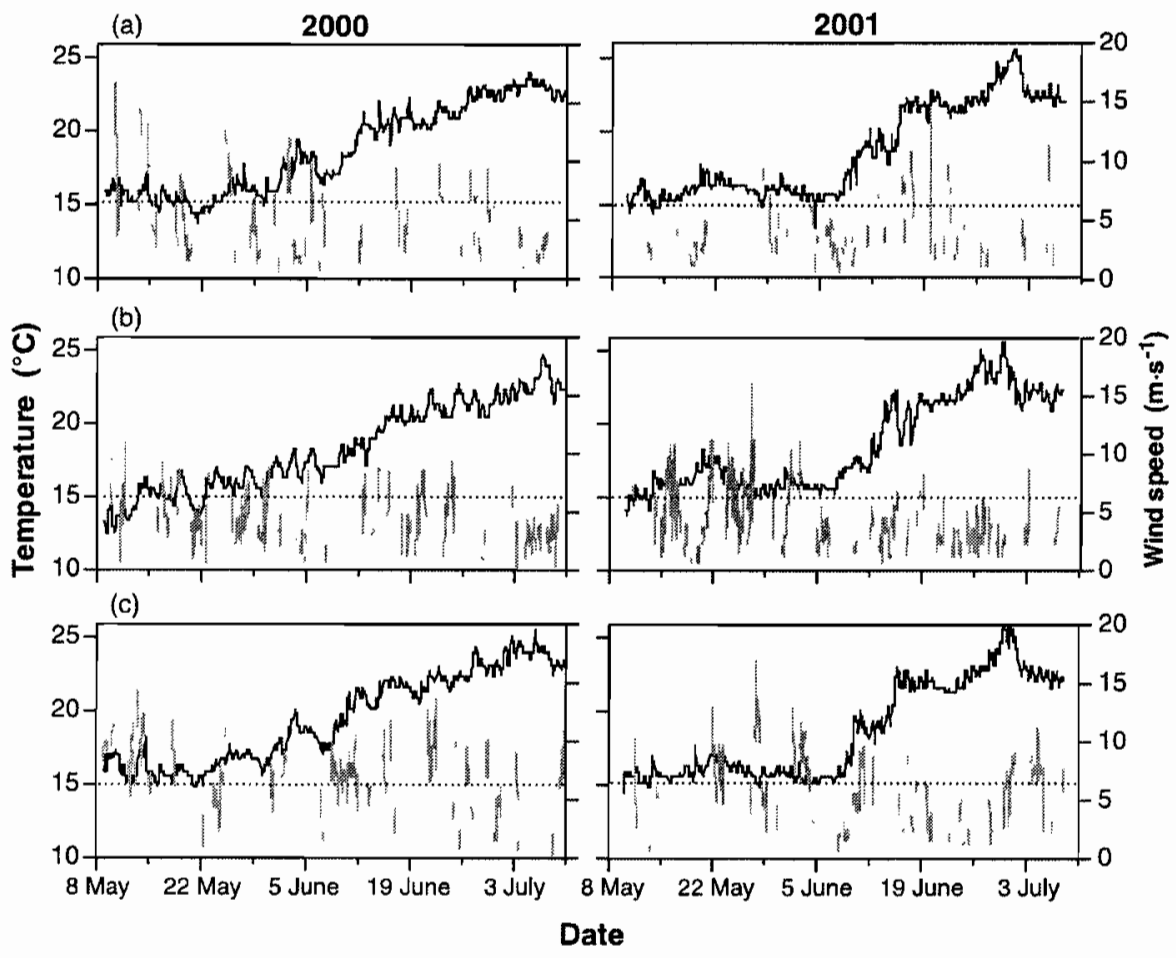

Table 3. Mayfield estimates of smallmouth bass (Micropterus dolomieu) daily nest survival based on treatment and the number of storms that the nest experienced.

\begin{tabular}{lllll}
\hline & \multicolumn{4}{l}{ Number of storms that a nest experienced } \\
\cline { 2 - 5 } Treatment & 0 & 1 & 2 & 3 \\
\hline Control & $0.98(125)$ & $0.89(114)$ & $0.89(57)$ & $0.42(18)$ \\
Angling without predation & $0.94(68)$ & $0.89(47)$ & $0.72(27)$ & $0.56(9)$ \\
Angling with predation & $0.93(73)$ & $0.87(51)$ & $0.81(28)$ & $0.24(8)$ \\
\hline
\end{tabular}

Note: Parenthetical numbers indicate the number of nests used for each calculation from a total of 266 smallmouth bass nests sampled in the Bass Islands, Lake Erie, during 1999-2001.

\section{Storms and nest success}

A 2DKS test identified a significant threshold where artificial nests lost an average of $75 \%$ of their eggs when exposed to at least $2 \mathrm{~h}$ of consecutive wind speeds of at least $7 \mathrm{~m} \cdot \mathrm{s}^{-1}$. We used this strength and duration of wind speeds as our definition of a storm capable of destroying smallmouth bass nests. From artificial nest experiments, we determined that wind speeds of this strength and duration resulted in significant egg losses from artificial nests (2DKS test, $N=$ $33, D=0.12(D$ is the test statistic used in a $2 \mathrm{DKS}$ test (explained in Garvey et al. 1998)), $P=0.03$ ). Egg losses from nests with small or large substrates did not differ ( $t=$ 1.98 , $\mathrm{df}=138, P=0.51$ ). Using our definition of a storm, we counted the number of storms of the proper direction that occurred at each site within the dates that we observed active nests that were not yet successful. Storm number was negatively correlated with nest success and explained $55 \%$ of the variance in smallmouth bass nest success (controls only; Fig. 3).

We found no clear pattern of changing water temperature at the 3-m depth associated with storms (Fig. 4). The mean change in water temperature from $6 \mathrm{~h}$ preceding a storm to $6 \mathrm{~h}$ following a storm averaged $-0.04{ }^{\circ} \mathrm{C}$ (range -2.1 to $+4.0^{\circ} \mathrm{C}$ ) and was split equally between increasing and decreasing temperatures. In addition, only one storm during this period was accompanied by a decline of more than $2^{\circ} \mathrm{C}$ and only four storms were associated with drops of more than $1{ }^{\circ} \mathrm{C}$. Following storms on 19 May 2000 at Perry's Monument, there was a steady temperature drop to below $14{ }^{\circ} \mathrm{C}$ and all 13 active nests (includes all treatments) failed.

\section{Mayfield estimation of nest survival}

The Mayfield estimate of daily survival rate for the control treatment $(0.92)$ was higher than both the angling with- 
Table 4. Summary of model results for smallmouth bass (Micropterus dolomieu) nest survival in Lake Erie, 1999-2001.

\begin{tabular}{llllcll}
\hline Model & Deviance & $\begin{array}{l}\text { No. of } \\
\text { parameters }\end{array}$ & $\mathrm{AIC}_{\mathrm{c}}$ & $\Delta \mathrm{AIC}_{\mathrm{c}}$ & $\begin{array}{l}\text { Model } \\
\text { weight }\left(w_{i}\right)\end{array}$ & $\begin{array}{l}\text { Model } \\
\text { likelihood }\end{array}$ \\
\hline$S_{\text {(trt storms) }}$ & 589.58 & 4 & 597.60 & 0.00 & 0.62 & 1.00 \\
$S_{\text {(ttorms) }}$ & 596.82 & 2 & 600.83 & 3.22 & 0.12 & 0.20 \\
$S_{\text {(trt) }}$ & 595.03 & 3 & 601.05 & 3.45 & 0.11 & 0.18 \\
$S_{\text {(trtxstorms) }}$ & 589.36 & 6 & 601.42 & 3.81 & 0.09 & 0.15 \\
$S_{\text {(trt+storm hours) }}$ & 594.67 & 4 & 602.70 & 5.10 & 0.05 & 0.08 \\
$S_{(\cdot)}$ & 606.94 & 1 & 608.94 & 11.34 & 0.00 & 0.00 \\
$S_{\text {(site) }}$ & 606.84 & 3 & 612.86 & 15.26 & 0.00 & 0.00 \\
\hline
\end{tabular}

Note: Akaike's Information Criterion $\left(\mathrm{AIC}_{\mathrm{c}}\right)$ values are used to rank the models. In general, when the difference in $\mathrm{AlC}_{\mathrm{c}}$ values $\left(\triangle \mathrm{AIC}_{\mathrm{c}}\right)$ is $<2$, then there is equal support for the models. Factors in the models include storms, nest treatment (trt: control, angling, and angling plus nest predation), and site.

out predation treatment $(0.86 ; z=3.07, P=0.002)$ and the angling with predation treatment $(0.86 ; z=3.07, P=0.002)$. There was no difference in daily survival of the two angling treatments $(z=0.10, P=0.92)$. After splitting the nest histories depending on the number of storms, daily survival rates decreased as the number of storms that a nest experienced increased (Table 3). Implications of differences in daily survival are magnified when considering that smallmouth bass offspring typically require at least 2 weeks to develop into free-swimming larvae (for successful nests, mean = 13 days during this study). Because parental care can last up to 43 days (Friesen 1998; Knotek and Orth 1998), we extrapolated our daily survival rates to 20 -day survival rates. When nests had not experienced a storm, control nests were 2.4-3 times more likely to survive 20 days than those of either of the angling treatments (Fig. 5). Storms dramatically decreased nest survival; after experiencing just a single storm, control nests had only a 0.10 probability of surviving 20 days, while those experiencing no storms had a 0.68 probability of surviving 20 days (Fig. 5).

\section{MARK estimation of nest survival}

Daily survival of smallmouth bass nests was a function of number of storms and treatment (Table 4). The best model, $S_{(\text {trt }+ \text { storms })}$ was more than five times more likely to describe nest survival than the next best model, $S_{\text {(storms) }}$. From the best model, storms negatively affected nest success $\left(\beta_{\text {storms }}=-0.074\right)$, as did angling $\left(\beta_{\text {angling without predation }}=-0.45, \beta_{\text {angling with predation }}=-0.41\right.$ ). When we considered each of these factors alone, storms and nest treatment had equal weight in determining nest success $\left(S_{\text {(trt) }} \mathrm{AIC}_{\mathrm{c}}-S_{\text {(storms) }} \mathrm{AIC}_{\mathrm{c}}=0.230\right.$ ) (Table 4). Using total number of storm hours did not explain nest success as well as using total number of storms ( $S_{\text {(trt+storms) }} \mathrm{AIC}_{\mathrm{c}}-S_{\text {(trt+storm hours) }} \mathrm{AIC}_{\mathrm{c}}=$ 5.10) (Table 4). In other words, storm duration was not as important as absolute number of storms in determining daily nest survival. In addition, the model including only additive effects of storm number and nest treatment was seven times more likely than the model with an interaction between the effects of storm number and nest treatment, suggesting that these covariates had only additive effects on daily nest survival.

Mean daily nest survival ranged from a low of 0.83 (angling without predation treatment at Perry's Monument, 2000,10 storms) to a high of 0.93 (control treatment at
Fig. 5. Probability that a smallmouth bass (Micropterus dolomieu) nest survived 20 days in the Bass Islands, Lake Erie, during 1999-2001 given its exposure to storms, angling, and nest predation during angling $(\boldsymbol{\square}$, control; $\boldsymbol{\bullet}$, angling without predation; $\boldsymbol{\Lambda}$, angling with predation). Mayfield estimates of daily nest survival were raised to the power of 20 to adjust daily survival to a typical duration of parental care. No nests survived three storms. Error bars indicate the $95 \%$ confidence interval.

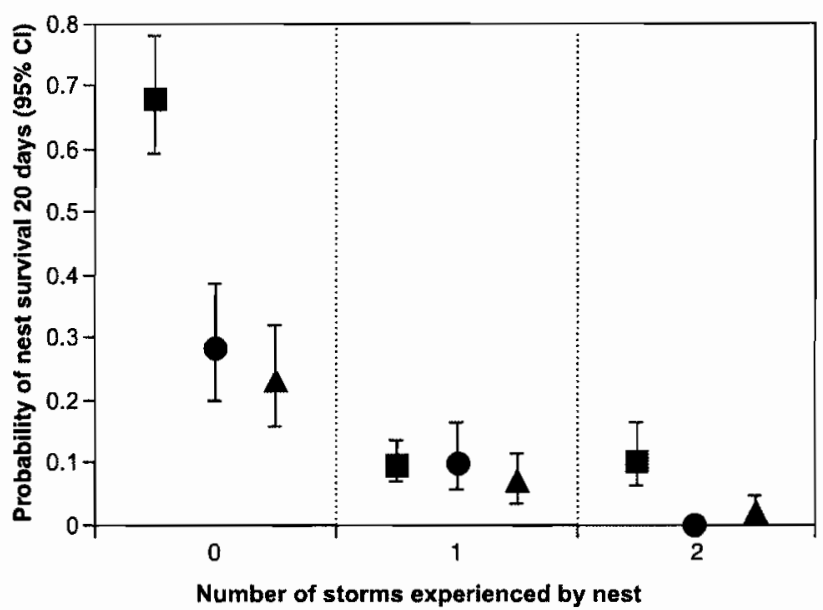

Perry's Monument, 1999, two storms). Overall, mean daily survival for control nests (0.91) was higher than for those of the angling without predation treatment $(0.87)$ and angling with predation treatment $(0.88)$. When expanding daily survival rates to 20-day survival rates, nest survival rates were $0.09-0.25$ for control nests and 0.02 to 0.10 for nests of either angling treatment (Fig. 6).

\section{Discussion}

Smallmouth bass nest success in the Bass Islands, Lake Erie, was lower than reported in many other systems, except for studies in the Great Lakes, because of frequent, powerful storms. Storms may destroy smallmouth bass nests by causing upwelling of cold water that kills developing offspring or by physically damaging or washing the offspring from the 
Fig. 6. Probability that a smallmouth bass (Micropterus dolomieu) nest survived 20 days in the Bass Islands, Lake Erie, given its location ( $\mathbf{\square}$, Perry's Monument; $\mathbf{0}$, Gray's Bay; $\boldsymbol{\Lambda}$, Sonny's Marina) and exposure to angling and nest predation during angling: $(a)$ control, $(b)$ angling without predation, and (c) angling with predation. Survival probabilities for each site and nest treatment are from the best-fit model calculated in the program MARK ( $S_{(\text {trt }+ \text { storms })}$ ) raised to the power of 20 to adjust daily survival to a typical duration of parental care. Error bars indicate the $95 \%$ confidence interval.

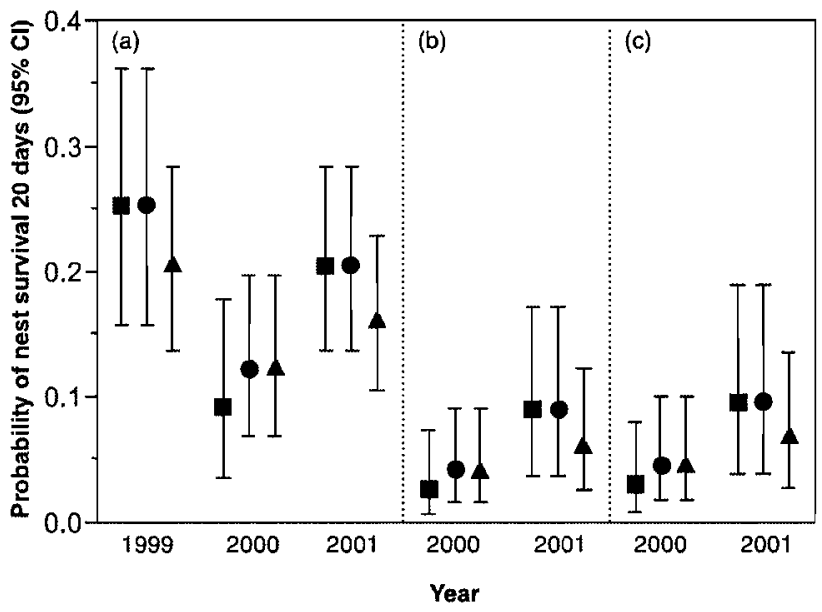

nest. Our artificial nest experiment simulated only the unhatched embryo stage, and hatched embryos likely have a different susceptibility to physical forces. However, we used this experiment only to define a storm for the remainder of our analyses, and with our definition, we found consistent support that storms have the potential to reduce smallmouth bass nest success. We found no consistent pattern of increasing or decreasing water temperatures following storm events, but we cannot discount that temperature changes may have led to some nest failures. But reports of temperature influences on smallmouth bass nest success are not consistent. In the laboratory, transferring unhatched smallmouth bass embryos from 18 to $10^{\circ} \mathrm{C}$ had no adverse affect (Webster 1945). But in field observations, fungus infected and killed smallmouth bass offspring when temperatures dropped below $18^{\circ} \mathrm{C}$ (Knotek and Orth 1998). In addition, evidence from Lake Opeongo suggests that temperature declines $>2{ }^{\circ} \mathrm{C}$ may cause nest failures (Friesen 1998; Steinhart 2004), but only once did we observe a temperature decline $>2{ }^{\circ} \mathrm{C}$ following a storm.

In contrast, many studies have concluded that storms and high flows flush offspring from nests (Goff 1986; Lukas and Orth 1995). In particular, a study in Long Point Bay, Lake Erie, documented that storms destroyed smallmouth bass nests when wind speeds were $>4.6 \mathrm{~m} \cdot \mathrm{s}^{-1}$ (Goff 1986). We found that higher wind speeds were required to destroy smallmouth bass nests, but the smallmouth bass nests in our study were in deeper water (average nest was in $3.0 \mathrm{~m}$ of water) than in Long Point Bay (average nest was in $1.6 \mathrm{~m}$ of water). We used our definition of a storm to estimate nest survival for nests of different ages even though our artificial nests simulated only unhatched embryos. It is difficult to predict whether unhatched or hatched embryos are more susceptible to storm-generated currents. Unhatched embryos are often found on exposed surfaces and are adhesive. Hatched embryos settle into crevices in the substrate and are not adhesive. Future work should focus on estimating water velocities that wash smallmouth bass embryos (both hatched and unhatched embryos) and larvae from nests on different substrates and at different depths. Then, researchers could define wind speeds capable of destroying smallmouth bass nests in a variety of systems and water depths. Regardless of the mechanism, physical damage, removal from nest, or temperature change, there was clear evidence that smallmouth bass nest survival was reduced by storms.

In Lake Erie, nest success was negatively related to angling but not to nest predation. Catch-and-release of nestguarding males also has been shown to reduce the probability of nest success (Philipp et al. 1997), but the mechanism has not been clearly defined. Some researchers have suggested that angling may cause males to abandon when the male returns and finds a smaller brood following nest predation (Kieffer et al. 1995; Suski et al. 2003). In Lake Erie, nest predators consumed 400-1000 offspring every time a male smallmouth bass was caught and released (Steinhart et al. 2004). Despite these offspring losses, we found that nest predation during angling did not cause a reduction in smallmouth bass nest success in Lake Erie. Additional offspring losses may occur during recovery from angling-related physiological stress if nest-guarding fish are not able to adequately defend their nest (Kieffer et al. 1995; Schreer et al. 2001; Cooke et al. 2002); thus, postangling nest predation also has been suggested. We have no evidence that brood predation occurred after the male returned to its nest in Lake Erie (Steinhart et al. 2004). Furthermore, in experimental brood reductions $(25 \%-75 \%$ of offspring removed) in Lake Erie, 10 of 11 males continued to guard their broods for at least 2 days (mean 6 days, range $0-19$ days) after brood reduction, and except for one nest that was abandoned within 1 day, all other nests were guarded until a storm occurred (G.B. Steinhart, unpublished data). However, experimental brood reductions in other lakes reduced male brood defense (Ridgway 1989; Suski et al. 2003) and nest success (Suski et al. 2003). For other fish species, brood reduction causes either no difference (Jennions and Polakow 2001) or an increase (Coleman et al. 1985) in brood abandonment. Different behavioral responses to brood size might be explained by probability of successful future reproduction and expected future fitness. In Lake Erie, high angling pressure reduces adult survival, and males maximizing their expected lifetime fitness almost always guarded their nests, regardless of brood size (Steinhart 2004). In other systems (e.g., those with high adult survival), optimal males abandoned when their brood became too small (Coleman et al. 1985; Suski et al. 2003; Steinhart 2004).

Angling had a direct negative effect on smallmouth bass nest success in Lake Erie, as it has in other systems (Philipp et al. 1997; Suski et al. 2002). For both angling treatments, nest success and daily survival rate were reduced compared with control nests. Our study areas were open to recreational anglers during the course of our study, so nest-guarding males may have been angled without our knowledge. Be- 
cause all males of all treatments were vulnerable to anglers, this should not bias the differences between treatments, although overall nest survival may have been reduced owing to undocumented angling. In addition, our experimental angling may have underestimated nest survival owing to angling if jaw-tagged males made them more likely to abandon. In one study, however, mortality of jaw-tagged male smallmouth bass was the same as for non-jaw tagged males $(\sim 10 \%)$ during nesting (MacCrimmon and Robbins 1979). Jaw tags also can reduce adult growth rates (Shetter 1967), but this should have had little effect during the short time nests were present after the angling treatment (maximum of 16 days).

Several explanations exist as to why angling may have reduced smallmouth bass nest success. First, angling can cause smallmouth bass mortality, but immediate $(<1 \mathrm{~h})$ and shortterm $(<72$ h) mortalities are low (Dunmall et al. 2001), even when fish are subjected to repeated handling and extensive confinement in tournaments $(0 \%-11 \%$ mortality; Hartley and Moring 1995). Others have hypothesized that anglingrelated physiological stress causes angled males to abandon (Cooke et al. 2002). In fact, as the number of times that a male is caught increases, nest success decreases (Philipp et al. 1997). The physiological stress and energetic expenditures during catch-and-release angling, combined with the large amounts of energy invested in parental care (Gillooly and Baylis 1999; Mackereth et al. 1999), may push smallmouth bass over a threshold beyond which nest abandonment becomes the favorable choice to improve the probability of successfully reproducing the following season. Smallmouth bass in Lake Erie already lose a significant amount of energy defending their brood (Steinhart et al. 2005). Regardless of the exact mechanism, some factor related to stress from angling probably is responsible for the reduced smallmouth bass nest success in Lake Erie.

We conclude that storms had the greatest impact on smallmouth bass nest success in Lake Erie but that angling also caused some males to abandon their nests. The effects of storms and angling were independent; that is, angled and control nests were affected by storms equally. While storms destroyed many smallmouth bass nests in the Bass Islands, storms might have little effect on smallmouth bass nest success in small lakes where storms are not as intense as in large lakes. Although nest predators (i.e., round gobies) are extremely abundant in Lake Erie, nest predation during angling had no effect on nest survival despite the high offspring mortality while the guarding male was absent (Steinhart et al. 2004). What remains to be determined is whether patterns in smallmouth bass nest success drive patterns in adult abundance. Many studies have failed to find a relationship between nest success or young-of-the-year abundance and adult abundance (Serns 1984; Post et al, 1998; Gillooly et al. 2000). Despite this uncertainty, our study corroborates other research that has demonstrated that angling for nest-guarding bass reduces nest success (Kieffer et al. 1995; Philipp et al. 1997; Suski et al. 2003).

\section{Acknowledgements}

We thank the Ohio Department of Natural Resources, Division of Wildlife, for their assistance with this project. Paul
Doherty was very helpful in teaching us how to prepare our data, design appropriate models, and interpret our results from the program MARK. Tom Grubb, Clifford Kraft, Jesse Lepack, Dana Warren, Brian Weidel, Dan Wiegmann, and two anonymous reviewers provided comments that improved this manuscript. We also thank personnel at Ohio State University Aquatic Ecology Laboratory and F.T. Stone Laboratory and the many researchers who helped us in the field. This research was funded by Federal Aid in Sport Fish Restoration Project F-69-P administered jointly by the US Fish and Wildlife Service and Ohio Department of Natural Resources, Division of Wildlife, and the Department of Evolution, Ecology, and Organismal Biology at Ohio State University.

\section{References}

Akaike, H. 1985. Prediction and entropy. In A celebration of statistics. Edited by A.C. Atkinson and S.E. Fienberg. Springer-Verlag, New York. pp. 1-24.

Burnham, K.P., and Anderson, D.R. 1998. Model selection and inference: a practical information-theoretic approach. Springer-Verlag, New York.

Charlebois, P.M., Marsden, E.J., Goettel, R.G., Wolfe, R.K., Jude, D.J., and Rudnika, S. 1997. The round goby, Neogobius melanostomus (Pallas), a review of European and North American literature. Illinois-Indiana Sea Grant Program and Illinois Natural History Survey, Champaign, Ill. Rep. Spec. Publ. No. 20.

Chotkowski, M.A., and Marsden, E.J. 1999. Round goby and mottled sculpin predation on lake trout eggs and fry: field predictions from laboratory experiments. J. Gt. Lakes Res. 25: 26-35.

Coleman, R.M., Gross, M.R., and Sargent, R.C. 1985. Parental investment decision rules: a test in bluegill sunfish. Behav. Ecol. Sociobiol. 18: 59-66.

Cooke, S.J., Schreer, J.F., Wahl, D.H., and Philipp, D.P. 2002. Physiological impacts of catch-and-release angling practices on largemouth bass and smallmouth bass. In Black bass: ecology, conservation, and management. Edited by D.P. Philipp and M.S. Ridgway. American Fisheries Society, Bethesda, Md. Am. Fish. Soc. Symp. 31: 489-512.

Crisp, D.T. 1989. Use of artificial eggs in studies of washout depth and drift distance for salmonid eggs. Hydrobiologia, 178: 153-163.

Dinsmore, S.J., White, G.C., and Knopf, F.L. 2002. Advanced techniques for modeling avian nest survival. Ecology, 83: 3476-3488.

Dudley, R.K., and Platania, S.P. 1999. Imitating the physical properties of drifting semibuoyant fish (Cyprinidae) eggs with artificial eggs. J. Freshw. Ecol. 14: 423-430.

Dunmall, K.M., Cooke, S.J., Schreer, J.F., and McKinley, R.S. 2001. The effect of scented lures on the hooking injury and mortality of smallmouth bass caught by novice and experienced anglers. N. Am. J. Fish. Manag. 21: 242-248.

Farnsworth, G.L., Weeks, K.C., and Simons, T.R. 2000. Validating the assumptions of the Mayfield method. J. Field Ornithol. 71: 658-664.

Friesen, T.G. 1998. Effects of food abundance and temperature on growth, survival, development and abundance of larval and juvenile smallmouth bass. Ph.D. dissertation, University of Guelph, Guelph, Ont.

Garvey, J.E., Marschall, E.A., and Wright, R.A. 1998. From starcharts to stoneflies: detecting relationships in continuous bivariate data. Ecology, 79: 442-447.

Ghalambor, C.K., and Martin, T.E. 2000. Parental investment strategies in two species of nuthatch vary with stage-specific predation risk and reproductive effort. Anim. Behav. 60: 263267. 
Gillooly, J.F., and Baylis, J.R. 1999. Reproductive success and the energetic cost of parental care in male smallmouth bass. J. Fish Biol. 54: 573-584.

Gillooly, J.F., O'Keefe, T.C., Newman, S.P., and Baylis, J.R. 2000. A long-term view of density-dependent recruitment in smallmouth bass from Nebish Lake, Wisconsin. J. Fish Biol. 56: 542-551.

Goff, G.P. 1986. Reproductive success of male smallmouth bass in Long Point Bay, Lake Erie. Trans. Am. Fish. Soc. 115: 415-423.

Gross, M.R., and MacMillan, A.M. 1981. Predation and the evolution of colonial nesting in bluegill sunfish (Lepomis macrochirus). Behav. Ecol. Sociobiol. 8: 163-174.

Hartley, R.A., and Moring, J.R. 1995. Differences in mortality between largemouth and smallmouth bass caught in tournaments. N. Am. J. Fish. Manag. 15: 666-670.

Hinch, S.G., and Collins, N.C. 1991. Importance of diurnal and nocturnal nest defense in the energy budget of male smallmouth bass: insights from direct video observation. Trans. Am. Fish. Soc. 120: 657-663.

Hurley, G.V. 1975. The reproductive success and early growth of smallmouth bass, Micropterus dolomieu Lacepede, at Baie du Dore, Lake Huron, Ontario. M.S. thesis, University of Toronto, Toronto, Ont.

Janssen, J., and Jude, D.J. 2001. Recruitment failure of mottled sculpin Cottus bairdi in Calumet Harbor, southern Lake Michigan, induced by the newly introduced round goby Neogobius melanostomus. J. Gt. Lakes Res. 27: 319-328.

Jennions, M.D., and Polakow, D.A. 2001. The effect of partial brood loss on male desertion in a cichlid fish: an experimental test. Behav. Ecol. 12: 84-92.

Johnson, D.H. 1979. Estimating nest success: the Mayfield method and an alternative. Auk, 96: 651-661.

Johnson, T.B., Allen, M., Corkum, L.D., and Lee, V.A. 2005. Comparison of methods needed to estimate population size of round gobies (Neogobius melanostomus) in western Lake Erie. J. Gt. Lakes Res. 31: 78-86.

Kieffer, J.D., Kubacki, M.R., Phelan, F.J.S., Philipp, D.P., and Tufts, B.L. 1995. Effects of catch-and-release angling on nesting male smallmouth bass. Trans. Am. Fish. Soc. 124: 70-76.

Knotek, W.L., and Orth, D.J. 1998. Survival for specific life intervals of smallmouth bass, Micropterus dolomieu, during parental care. Environ. Biol. Fishes, 51: 285-296.

Latta, W.C. 1956. The life history of the smallmouth bass, Micropterus d. dolomieui, at Waugoshance Point, Lake Michigan. Institute for Fisheries Research (Michigan Department of Conservation) and the University of Michigan, Ann Arbor, Mich. Bull. Inst. Fish. Res. Rep. No. 5.

Lukas, J.A., and Orth, D.J. 1995. Factors affecting nesting success of smallmouth bass in a regulated Virginia stream. Trans. Am. Fish. Soc. 124: 726-735.

MacCrimmon, H.R., and Robbins, W.H. 1979. Suitability of jaw tags and Atkins stream tags for marking smallmouth bass Micropterus dolomieui. Trans. Am. Fish. Soc. 108: 499-501.

Mackereth, R.W., Noakes, D.L.G., and Ridgway, M.S. 1999. Sizebased variation in somatic energy reserves and parental care expenditure by male smallmouth bass, Micropterus dolomieu. Environ. Biol. Fishes, 56: 263-275.

Manly, B.F.J., and Schmutz, J.A. 2001. Estimation of brood and nest survival: comparative methods in the presence of heterogeneity. J. Wild. Manag. 65: 258-270.

Mayfield, H.F. 1961. Nesting success calculated from exposure. Wilson Bull. 73: 255-261.

Mayfield, H.F. 1975. Suggestions for calculating nest success. Wilson Bull. 87: 456-466.
Neves, R.J. 1975. Factors affecting fry production of smallmouth bass (Micropterus dolomieui) in South Branch Lake, Maine. Trans. Am. Fish. Soc. 103: 83-87.

Pease, C.V., and Grzybowski, J.A. 1995. Assessing the consequences of brood parasitism and nest predation on seasonal fecundity in passerine birds. Auk, 112: 343-363.

Philipp, D.P., Toline, C.A., Kubacki, M.F., and Philipp, D.B.F. 1997. The impact of catch-and-release angling on the reproductive success of smallmouth bass and largemouth bass. N. Am. J. Fish. Manag. 17: 557-567.

Popiel, S.A., Perez-Fuentetaja, A., McQueen, D.J., and Collins, N.C. 1996. Determinants of nesting success in the pumpkinseed (Lepomis gibbosus): a comparison of two populations under different risks of predation. Copeia, 1996: 649-656.

Post, D.M., Kitchell, J.F., and Hodgson, J.R. 1998. Interactions among adult demography, spawning date, growth rate, predation, overwinter mortality, and the recruitment of largemouth bass in a northern lake. Can. J. Fish. Aquat. Sci. 55: 2588-2600.

Raffetto, N.S., Baylis, J.R., and Serns, S.L. 1990. Complete estimates of reproductive success in a closed population of smallmouth bass (Micropterus dolomieui). Ecology, 71: 1523-1535.

Ricciardi, A., and Rasmussen, J.B. 1998. Predicting the identity and impact of future biological invaders: a priority for aquatic resource management. Can. J. Fish. Aquat. Sci. 55: 1759-1765.

Ridgway, M.S. 1989. The parental response to brood size manipulation in smallmouth bass (Micropterus dolomieui). Ethology, 80: $47-54$.

Ridgway, M.S., and Shuter, B.J. 1994. The effects of supplemental food on reproduction in parental male smallmouth bass. Environ. Biol. Fishes, 39: 201-207.

Sargent, R.C. 1988. Parental care and egg survival both increase with clutch size in the fathead minnow, Pimephales promelas. Behav. Ecol. Sociobiol. 23: 33-37.

Schreer, J.F., Cooke, S.J., and McKinley, R.S. 2001. Cardiac response to variable forced exercise at different temperatures: an angling simulation for smallmouth bass. Trans. Am. Fish. Soc. 130: 783-795.

Serns, S.L. 1984. Relation of water temperature and population density to first-year recruitment and growth of smallmouth bass in a Wisconsin lake. Trans. Am. Fish. Soc. 111: 570-574.

Shetter, D.S. 1967. Effects of jaw tags and fin excision upon the growth, survival, and exploitation of hatchery rainbow trout fingerlings in Michigan. Trans. Am. Fish. Soc. 96: 394-399.

Shuter, B.J., and Post, J.R. 1990. Climate, population viability, and the zoogeography of temperate fishes. Trans. Am. Fish. Soc. 119: 314-336.

Steinhart, G.B. 2004. Exploring factors affecting smallmouth bass nest success and reproductive behavior. $\mathrm{Ph} . \mathrm{D}$. dissertation, Ohio State University, Columbus, Ohio.

Steinhart, G.B., Marschall, E.A., and Stein, R.A. 2004. Round goby predation on smallmouth bass offspring in nests during simulated catch-and-release angling. Trans. Am. Fish. Soc. 133: $121-131$.

Steinhart, G.B., Sandrene, M.E., Weaver, S., Stein, R.A., and Marschall, E.A. 2005. Increased parental care cost for nestguarding fish in a lake with hyperabundant nest predators. Behav. Ecol. 16: 472-434.

Suski, C.D., Phelan, F.J.S., Kubacki, M.F., and Philipp, D.P. 2002. The use of sanctuaries for protecting nesting black bass from angling. In Black bass: ecology, conservation, and management. Edited by D.P. Philipp and M.S. Ridgway. American Fisheries Society, Bethesda, Md. Am. Fish. Soc. Symp. 31: 371-378.

Suski, C.D., Svec, J.H., Ludden, J.B., Phelan, F.J.S., and Philipp, D.P. 2003. The effect of catch-and-release angling on the paren- 
tal care behavior of male smallmouth bass. Trans. Am. Fish. Soc. 132: 210-218.

Townshend, T.J., and Wootton, R.J. 1985. Adjusting parental investment to changing environmental conditions: the effect of food ration on parental behavior of the convict cichlid, Cichlasoma nigrofasciatum. Anim. Behav. 33: 494-501.

Turner, G.E., and MacCrimmon, H.R. 1970. Reproduction and growth of smallmouth bass, Micropterus dolomieui, in a Precambrian lake. J. Fish. Res. Board Can. 27: 395-400.
Webster, D.A. 1945. Relation of temperature to survival and incubation of the eggs of smallmouth bass (Micropterus dolomieu). Trans. Am. Fish. Soc. 75: 43-47.

White, G.C., and Burnham, K.P. 1999. Program MARK: survival estimation from populations of marked animals. Bird Study, 46: 120-138. 